Nowoczesne Systemy Zarządzania

Zeszyt 12 (2017), nr 3 (lipiec-wrzesień)

ISSN 1896-9380, s. 95-105

Modern Management Systems

Volume 12 (2017), No. 3 (July-September)

ISSN 1896-9380, pp. 95-105
Instytut Organizacji i Zarządzania

Wydział Cybernetyki

Wojskowa Akademia Techniczna

w Warszawie

Institute of Organization and Management

Faculty of Cybernetics

Military University of Technology

\title{
Innowacyjny model biznesowy jako determinanta efektywnego zarządzania przedsiębiorstwem
}

\section{Innovative business model as a determinant of effective enterprise management}

\author{
Patryk Wasiuk \\ Wojskowa Akademia Techniczna \\ Wydział Cybernetyki
}

\begin{abstract}
Abstrakt. Postępująca globalizacja oraz dynamika otoczenia sprawiają, że konkurowanie z firmami działającymi na rynku jest coraz trudniejsze. Jedną z metod osiągania oraz utrzymywania przewagi konkurencyjnej jest stworzenie modelu biznesowego z wykorzystaniem do tego celu innowacji. Ważne jest zrozumienie koncepcji oraz jej kluczowych elementów, dlatego w pierwszej kolejności w artykule zaprezentowane zostały różne podejścia do definiowania pojęcia modelu biznesowego; wyjaśniono też jego istotę oraz znaczenie. Następnie przedstawiono przykładowy szablon modelu biznesowego - model Canvas wraz z charakterystyką jego wszystkich elementów oraz obszarów.
\end{abstract}

Słowa kluczowe: model biznesowy, model biznesowy Canvas, przewaga konkurencyjna

Abstract. Increasing globalization and the dynamics of the environment makes the competition from the companies operating in the market is more and more difficult. One of the methods of achieving and maintaining a competitive advantage is to create a business model, taking advantage of the innovation. It is important to understand the concept and its key elements, so in the first place was presented different approaches to make definition of the concept of the business model, pointing to its essence and meaning. You will then be presented to a sample template business model - a model Canvas, together with the characteristics of its all components and areas.

Keywords: business model, business model Canvas, competitive advantage

\section{Wstęp}

Model biznesowy staje się coraz częściej niezbędnym elementem organizacji, dzięki któremu przedsiębiorstwo może osiągać trwałą przewagę konkurencyjną na 
rynku. W obecnym świecie nowe technologie, czy też zmiany produktowe, mogą już nie wystarczyć, aby osiągnąć sukces (Jankowski, Johnson, 2013, s. 108). Między innymi $z$ tego powodu proces planowania oraz zarządzania modelem biznesowym stał się niezwykle popularny w XXI wieku, o czym świadczy nagły wzrost liczby artykułów oraz publikacji na temat tej koncepcji (Osterwalder, Pigneur, 2012, s. 9). Jak trafnie dostrzegł B. Nogalski już w 2011 roku, modele biznesowe w najbliższym czasie miały stać się niezwykle pomocne m.in. w zarządzaniu współczesnym przedsiębiorstwem na różnych etapach jego funkcjonowania (Nogalski, 2011, s. 447). Słowa te stały się swoistą przepowiednią - w dzisiejszym otoczeniu biznesowym $\mathrm{z}$ łatwością można dostrzec coraz to nowsze oraz bardziej innowacyjne modele biznesowe, które wspomagają rozwój organizacji.

Celem niniejszego artykułu jest ukazanie modelu biznesowego jako współczesnej determinanty efektywnego zarządzania przedsiębiorstwem, dążącej do osiągnięcia oraz utrzymania przewagi konkurencyjnej. W opracowaniu szczególna uwaga zostanie zwrócona na elementy składowe modelu biznesowego oraz istniejące pomiędzy nimi powiązania i relacje w oparciu o model Canvas, a także na wartości generowane przez model biznesowy dla końcowego odbiorcy.

\section{Istota i znaczenie modelu biznesowego}

Postępująca globalizacja, a także rozwój internetu i e-biznesu sprawił, że pojęcie modelu biznesowego zyskało na znaczeniu. Stąd też należy zwrócić uwagę zarówno na sam termin „model biznesowy”, jak i jego znaczenie. Składa się on z dwóch wyrazów, z których każdy posiada odmienną definicję. Słownik języka polskiego PWN podaje następującą definicję słowa „model”: „wzór, według którego coś jest lub ma być wykonane” (PWN, 2016a), natomiast „biznes” definiuje następująco: "przedsięwzięcie handlowe lub produkcyjne przynoszące zysk” (PWN, 2016b). Zatem „model biznesowy” może oznaczać drogowskaz dla przedsiębiorstwa i jego kadry kierowniczej, który wyznacza optymalny kierunek, w jakim organizacja powinna podążać, by osiągnąć satysfakcjonujący zysk.

W dzisiejszym otoczeniu biznesowym łatwo jest znaleźć przedsiębiorstwa, podstawą sukcesu których są innowacyjne i dobrze zaprojektowane modele biznesowe. Co ciekawe, niemal połowa firm powstałych w ostatniej dekadzie i uwzględnionych w zestawieniu „Fortune 500” (lista największych przedsiębiorstw w okresie mijających 10 lat) znalazła się tam dzięki temu, że wykorzystywała innowacyjne modele biznesowe (Christensen, Johnson, Kagermann, 2008, s. 52).

$\mathrm{W}$ dziedzinie modeli biznesowych $\mathrm{z}$ innowacjami mamy do czynienia tak naprawdę od momentu powstania modeli organizacyjnych. To właśnie dzięki innowacjom organizacja może się wyróżnić na rynku na tle konkurencji. Dlatego też spełniają one tak ważną rolę w każdym modelu, o czym może świadczyć sukces firmy 
Diners Club, która w 1950 roku wprowadziła do obrotu kartę kredytową. Podobnie było w przypadku firmy Xerox, która w roku 1959 stosowała system naliczania opłat za każdą wykonaną kopię (Osterwalder, Pigneur, 2012, s. 9). Choć wydarzyło się to ponad 50 lat temu, pomysły te stanowią wzór dla dzisiejszych menedżerów, często wzorujących się na sprawdzonych pomysłach i modelach.

Jak trafnie zauważyli A. Osterwalder i Y. Pigneur, wszystkie innowacyjne modele biznesowe powstają głównie po to, aby generować określoną wartość - nie tylko dla końcowego klienta, ale także dla społeczeństwa. Każda organizacja działająca dzisiaj na rynku odgrywa ważną rolę - zaspokaja potrzeby otoczenia. Potrzeby te są różnorodne i w sposób ciągły ewoluują, stąd też konieczne jest stwarzanie czegoś, co może zastąpić przestarzałe już rozwiązania (Osterwalder, Pigneur, 2012, s. 9).

Omawiając istotę modelu biznesowego, nie sposób jest nie wspomnieć o najsłynniejszym sukcesie rynkowym, opartym na wdrożeniu innowacyjnego modelu biznesowego firmy Apple. Innowacja ta polegała głównie na wprowadzeniu na rynek iPoda (cyfrowy odtwarzacz muzyki) z jednoczesnym uruchomieniem internetowego sklepu iTunes.com, który oferował możliwość zakupu legalnej muzyki, przeznaczonej specjalnie dla tego urządzenia. Apple zrewolucjonizowało internetowy rynek muzyczny, stając się przy tym liczącym się, a następnie dominującym na nim graczem, wykorzystującym ogromny potencjał wynikający z zastosowania platformy wielostronnej. Co więcej, dzięki tej strategii firma Apple nie tylko osiągnęła pozycję lidera, ale i utrzymała prestiż wśród detalicznych sprzedawców muzyki w internecie (Osterwalder, Pigneur, 2012, s. 9, s. 89).

W literaturze przedmiotu można odnaleźć wiele definicji pojęcia modelu biznesowego. Jedną z pierwszych, ale i uważaną za najbardziej uniwersalną, jest ta podana przez P. Timmersa w 1998 roku. Według niego przez model biznesowy należy rozumieć strukturę (Timmers, 1998, s. 3-8):

- w której skład wchodzą: produkt, usługa oraz przepływ informacji;

- która powinna zawierać wyszczególnienie oraz charakterystykę tzw. aktorów biznesowych wraz z opisem ich roli;

- w której należy zdefiniować potencjalne korzyści, jakie mogą zostać osiągnięte przez określonych aktorów biznesowych.

Analizując literaturę pod kątem modeli biznesowych, z łatwością dostrzega się, że termin ten jest dość powszechnie używany, a mimo to pojawiają się problemy $z$ jego jednoznacznym zrozumieniem i zdefiniowaniem. Dlatego też konieczne jest przytoczenie kolejnego podejścia niezbędnego do projektowania, wdrażania, a także definiowania modelu biznesowego, opracowanego przez K. Obłoja: „model biznesowy to połączenie koncepcji strategicznej firmy i technologii jej praktycznej realizacji, rozumianej jako budowa łańcucha wartości pozwalającego na skuteczną eksploatację oraz odnowę zasobów i umiejętności”. Z definicji tej jasno wynika konieczność ścisłego związania przyjętej strategii organizacji ze sposobem jej praktycznego wdrażania. Wdrażanie to powinno być ukierunkowane na budowę takiego 
łańcucha wartości, który umożliwiłby skuteczne odnawianie eksploatowanych zasobów i umiejętności firmy. Kreowanie wartości oraz możliwość jej zatrzymywania zależna jest od trzech przesłanek tworzących trzon modelu (Obłój, 2002, s. 98):

- przewagi konkurencyjnej, rozumianej jako wymiar koncepcji modelu;

- zasobów oraz umiejętności;

- łańcucha wartości.

Model biznesowy przedsiębiorstwa można tak naprawdę definiować w wieloraki sposób - wszystko zależy od potencjału oraz wyobraźni firmy. Należy jednak pamiętać, że każdy model powinien odpowiadać na trzy zasadnicze pytania, związane z osiąganiem przewagi konkurencyjnej na rynku: co firma zamierza robić, jakie są jej kluczowe zasoby i kompetencje oraz w jaki sposób zasoby i kompetencje firmy są wykorzystywane w codziennym działaniu (Obłój, 2002, s. 97).

Problematykę modeli biznesowych porusza w swych pracach także J. Magretta. Jak słusznie zauważa, dobry model biznesowy jest podstawą każdej efektywnie działającej organizacji - bez względu na to, czy jest to przedsiębiorstwo dopiero wchodzące na rynek, czy też dojrzały podmiot gospodarczy. Autorka w sposób praktyczny definiuje modele biznesowe, traktując je jak opowieści, które wyjaśniają, w jaki sposób działa firma i gdzie zarabia pieniądze. Aby opowieść była wciągająca, musi spełniać następujące warunki: posiadać jasno określone postaci, wiarygodną motywację oraz akcję. Po przeczytaniu takiej opowieści, każdy czytelnik powinien z łatwością odpowiedzieć na pytania (Magretta, 2013, s. 54-56):

- Kto jest klientem?

- W jaki sposób zarabia się pieniądze w określonej branży/biznesie?

- Jak dostarczyć końcowemu klientowi określoną wartość, uwzględniając odpowiedni poziom kosztów?

Wydawać by się mogło, że udzielenie odpowiedzi na powyższe pytania nie powinno sprawiać trudności - jednak często, aby model biznesowy był w stanie generować określone odpowiedzi, pracownicy przedsiębiorstwa zmuszeni są przeznaczyć wiele miesięcy, a nawet lat, na opracowanie architektury modelu organizacyjnego. Mimo poświęconego czasu zawsze będzie istniała duża liczba niewiadomych - ze względu na zmieniające się otoczenie, czy też błędy bądź niedociągnięcia. Stąd też to, czy firma odniesie sukces, jest ściśle powiązane ze zdolnością przeprowadzania szybkich eksperymentów - a płynące z nich wnioski powinny zostać wykorzystane do ulepszenia modelu biznesowego. Pomocni w tym mogą okazać się nasi współpracownicy oraz partnerzy biznesowi, tj. agencje reklamowe, doradcy finansowi, a także „długa ławka” miejscowych przedsiębiorstw, znających lokalne wytyczne i realizujących nasz plan (Eyring, Johnson, Nair, 2012, s. 91, 99).

A. Afuah z kolei stwierdza, że każdy funkcjonujący model biznesowy składa się z komponentów, które zostały przedstawione na rysunku 1.

Zgodnie z powyższym poprzez model biznesowy należy rozumieć wszystkie działania, które w maksymalny sposób wykorzystują posiadane zasoby przy 
minimalizowaniu kosztów działalności i jednoczesnym uwzględnieniu czynników sektorowych, w efekcie umożliwiając osiąganie oraz utrzymywanie satysfakcjonującej pozycji na rynku, co przekłada się na zyskowność i rentowność firmy.

Codzienna działalność każdego przedsiębiorstwa wiąże się z dokonywaniem wyborów. Jak trafnie zauważył A. Afuah, wybory te mogą stać się bardziej oczywiste, kiedy odpowie się na poniższe pytania (Afuah, 2004, s. 9, Wierzbiński, 2015, s. 485):

1. Jakie działania zamierza wykonywać przedsiębiorstwo?

2. W jaki sposób działania te mają być wykonywane?

3. Kiedy i w jakim okresie działania te mają być wykonywane?

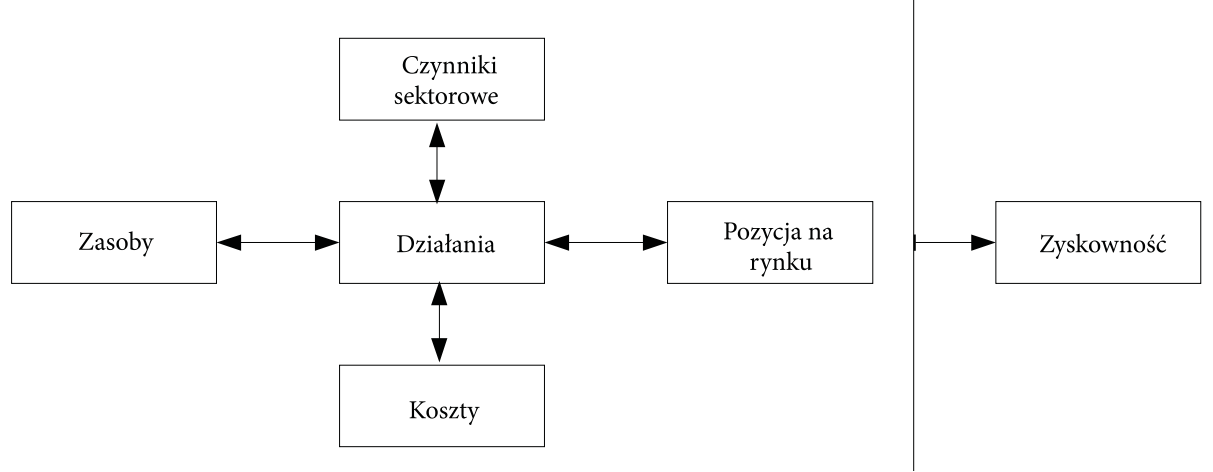

Rys. 1. Model biznesowy według A. Afuaha

Źródło: Afuah, 2004, s. 10

Odpowiedzi na te pytania należy udzielać tak, aby możliwe było generowanie określonej wartości dla klientów oraz uzyskanie wysokiej pozycji na rynku, umożliwiającej osiąganie ponadprzeciętnych zysków. A. Afuah we wcześniejszej swojej pracy (napisanej wraz z C.L. Tuccim) podjął się także próby zdefiniowania modelu biznesowego jako przyjętą z góry przez przedsiębiorstwo metodę, mającą na celu zarówno powiększanie, jak i wykorzystywanie zasobów w celu przedstawienia klientom takiej oferty projektów i usług, które będą się wyróżniać na tle konkurencji, jednocześnie zapewniając firmie określoną dochodowość (Afuah, Tucci, 2003, s. 20). Taki model w sposób szczegółowy określa plan przepływu pieniądza, odnosząc się zarówno do teraźniejszości, jaki i do przyszłości, a także wskazuje na kluczowe czynniki warunkujące zdobycie i długotrwałe utrzymanie przewagi konkurencyjnej w branży.

Współcześnie jest wiele determinant skutecznego zarządzania przedsiębiorstwem - jednym z takich czynników jest dobrze działający model biznesowy, który ma często podobny wpływ na funkcjonowanie organizacji, jak jej bezpośrednie otoczenie. Determinanty te - często pośrednio - wpływają znacząco na efektywność przedsiębiorstwa, co przekłada się na generowane zyski i tworzoną dla klienta wartość. Niewątpliwie modele biznesowe odgrywają ważną rolę w biznesie - i choć 
znanych jest wiele przykładów innowacyjnych modeli wdrażanych z sukcesem na skalę światową (np. Apple), to stosowanie innowacji w istniejących już modelach biznesowych wciąż spotyka się z oporem. Dlatego coraz częściej pojawia się pytanie - w jaki sposób stworzyć innowacyjny model biznesowy, wyróżniający nasze przedsiębiorstwo spośród konkurencji?

\section{Innowacyjny model biznesowy w ujęciu A. Osterwaldera - szablon Canvas}

Istnieje wiele technik i metod, które wskazują sposób tworzenia bądź doskonalenia już istniejącego modelu biznesowego. Na szczególną jednak uwagę zasługuje koncepcja wykorzystująca szablon Canvas - m.in. ze względu na rosnącą jej popularność w Polsce. Zainteresowanie tą koncepcją w naszym kraju w ciągu ostatnich kilku lat przedstawia rysunek 2 .

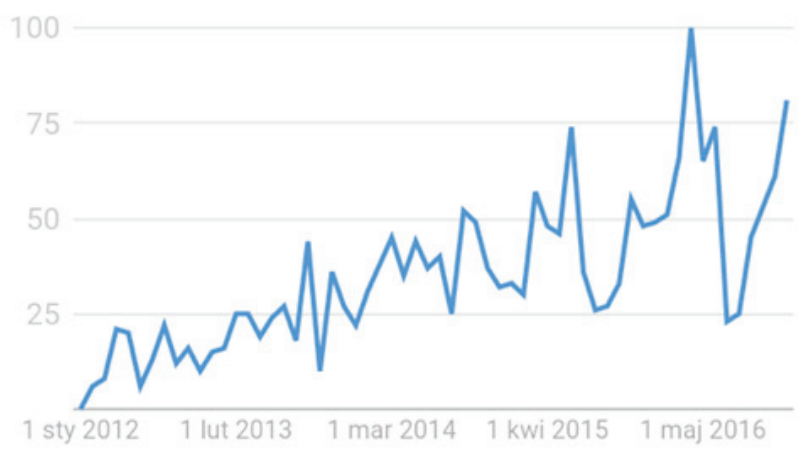

Rys. 2. Zainteresowanie hasłem 'model Canvas' w wyszukiwarce Google Źródło: Google, 2016

Z powyższego wykresu, na którym zaznaczona została aktywność polskich użytkowników wyszukiwarki Google, odczytać można, że hasło 'model Canvas' jest aktualnie wyszukiwane czterokrotnie częściej, niż miało to miejsce w roku 2012. Co ciekawe, największe zainteresowanie tym hasłem notuje się w województwie mazowieckim.

Szablon modelu biznesowego Canvas stał się znany w Polsce w 2012 roku, kiedy to na rynku ukazał się przekład książki napisanej przez A. Osterwaldera i Y. Pigneura we współpracy z 470 praktykami z tej dziedziny. Publikacja ta nosi tytuł Tworzenie modeli biznesowych. Podręcznik wizjonera i cieszy się ogromną popularnością na całym świecie; opisuje zarówno tradycyjne, jak i nowoczesne modele biznesowe, wskazując na ich dynamikę i innowacyjność modelu Canvas. W przekonaniu 
autorów każdy model biznesowy składa się z 9 stałych elementów i należy rozumieć go jako szkic strategii, która ma zostać wdrożona za pomocą struktur, procesów oraz systemów organizacji (Osterwalder, Pigneur, 2012, s. 19).

Model stworzony przez A. Osterwaldera można rozumieć jako całkowitą sumę zasobów (posiadanych przez przedsiębiorstwo) i czynności (realizowanych w ramach strategii organizacji), za pomocą których jednostka dostarcza konkretną wartość końcowemu klientowi. Nie bez powodu największą uwagę należy poświęcać sekcji związanej z propozycją wartości - to właśnie na jej podstawie budowane są pozostałe obszary modelu, w tym te związane z przychodami oraz kosztami przedsiębiorstwa.

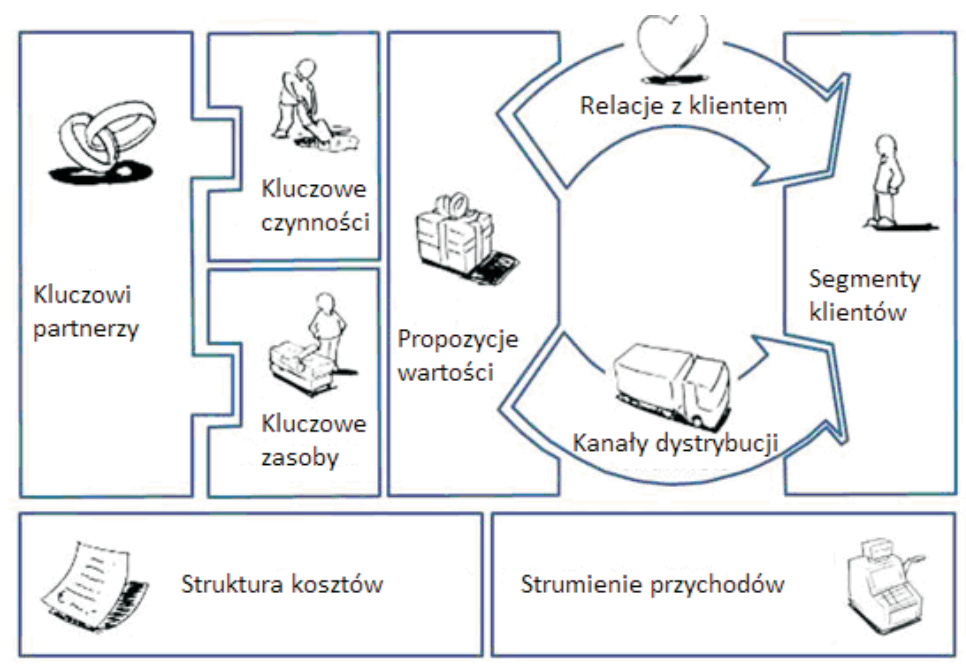

Rys. 3. Szablon modelu biznesowego Canvas Źródło: Web.gov.pl, 2016

Przedstawiony na rysunku 2 szablon modelu biznesowego podzielony został na dziewięć wzajemnie od siebie zależnych elementów. Elementy te można pogrupować w 4 zasadnicze obszary dotyczące: klientów, oferty, infrastruktury, a także aspektów finansowych.

\subsection{Elementy modelu Canvas dotyczące klientów}

W każdym modelu biznesowym głównym obszarem zainteresowania są potrzeby oraz wymagania klienta. Tak naprawdę wszystko to, co jest związane z osobą klienta, powinno stanowić priorytet przy opracowywaniu modelu biznesowego. W obszarze tym należy wyróżnić 3 elementy: segmenty klientów, kanały oraz relacje z klientami.

Segmenty klientów pełnią ważną funkcję - wskazują różne grupy klientów, do których stara się dotrzeć przedsiębiorstwo w celu dostarczenia określonej propozycji wartości. Aby jak najlepiej zrozumieć potrzeby potencjalnych klientów, 
firma dokonuje podziału rynku i grupuje ich w segmenty. O przydziale klienta do konkretnego segmentu decyduje najczęściej charakterystyczna cecha, zachowanie lub inna właściwość. W ramach jednego modelu biznesowego przedsiębiorstwo może obsługiwać kilka odrębnych segmentów - wtedy jednak firma do każdego $\mathrm{z}$ nich musi docierać za pośrednictwem osobnego kanału dystrybucji, niezbędne jest też ustanowienie różnych rodzajów relacji. Biorąc pod uwagę wszystkie kryteria wyodrębniania klientów, przykładowo można wyróżnić następujące rynki: masowy, niszowy oraz segmentację (Osterwalder, Pigneur, 2012, s. 24-25).

Kanały określają natomiast sposób, w jaki firma komunikuje się i dostarcza swoje propozycje wartości określonemu segmentowi klientów. Od procesu tego pośrednio zależy, jakiego rodzaju interakcje nawiążą się pomiędzy firmą, a jej klientami. Kanały pełnią wiele funkcji, w tym m.in. (Stępniewicz, 2012):

- Dostarczają klientom niezbędne informacje oraz wiedzę na temat produktów i usług oferowanych przez firmę,

- Umożliwiają klientom dokonanie zakupu produktów lub usług firmy,

- Zapewniają klientom wsparcie posprzedażowe,

- Pomagają klientom kształtować opinię na temat dostarczonej propozycji wartości.

Relacje $\mathrm{z}$ klientami stanowią kolejny element $\mathrm{w}$ modelu biznesowym; są to wszystkie relacje i interakcje, jakie łączą firmę z konkretnymi segmentami klientów. Relacje te mogą być zarówno bardzo osobiste (np. osobiste wsparcie), jak i w pełni zautomatyzowane. Należy podkreślić, że coraz więcej firm wykorzystuje w swojej działalności nowoczesny typ relacji, jakim jest współtworzenie - gdzie klient często jest współtwórcą wartości firmy (np. poprzez zamieszczanie recenzji przeczytanych książek). Wybór jasno określonej drogi, budowania relacji z klientami zależy tylko i wyłącznie od woli samego przedsiębiorstwa. Jednak firma musi mieć na względzie takie aspekty i cele jak: pozyskiwanie nowych i utrzymanie obecnych klientów, dążenie do zwiększenia sprzedaży, a także (o czym często się zapomina) integralność z pozostałymi elementami modelu biznesowego (Osterwalder, Pigneur, 2012, s. 32).

\subsection{Elementy modelu Canvas dotyczące oferty}

Kluczowym i jedynym elementem modelu Canvas odnoszącym się do oferowanych przez przedsiębiorstwo produktów jest propozycja wartości. Owa propozycja wartości jest to powód, dla którego klienci i odbiorcy wybierają ofertę danego przedsiębiorstwa, rezygnując z usług drugiej, konkurencyjnej firmy. Istotne jest, że to właśnie propozycja wartości rozwiązuje problemy klientów, bądź też prowadzi do zaspokajania ich potrzeb - są to więc wszystkie korzyści oferowane przez firmę. Oferta przedsiębiorstwa musi się zatem wyróżniać na tle konkurencji - propozycja wartości może mieć innowacyjny charakter i oferować coś nowego, niespotykanego 
wcześniej na rynku, bądź też firma może zaoferować obecne już na rynku produkty, wzbogacone o dodatkowe cechy lub atrybuty (Osterwalder, Pigneur, 2012, s. 26).

Propozycja wartości składa się z elementów o charakterze:

- ilościowym - np. cena, czas realizacji usługi;

- jakościowym - np. kompleksowa obsługa, design (Osterwalder, Pigneur, 2012, s. 27).

Katalog czynników generujących wartość dla klienta nie jest zamknięty. Wartość określonego produkty lub usługi to najczęściej indywidualna kwestia każdego człowieka. Firma powinna jednak zwrócić szczególną uwagę na takie elementy jak: nowość, wydajność, marka, wygoda, niższe koszty.

\subsection{Elementy modelu Canvas dotyczące infrastruktury}

W zarządzaniu przedsiębiorstwem ogromną rolę odgrywa jego infrastruktura, stąd też w modelu biznesowym nie mogło zabraknąć i tego obszaru. W skład procesu zarządzania infrastrukturą - w każdym modelu - wchodzą elementy dotyczące kluczowych czynności, zasobów, a także sieć partnerów.

Kluczowe czynności opisują sekwencję aktywności, które dana firm musi podjąć, aby dostarczyć wartość dla klienta, nawiązać z nim relację oraz generować przychody. To właśnie ten element w modelu biznesowym odpowiedzialny jest za sprawne jego funkcjonowanie. W praktyce często stosuje się podział kluczowych czynności na takie kategorie jak: produkcja, rozwiązywanie problemów (konfliktów), a także prowadzenie określonej platformy (Osterwalder, Pigneur, 2012, s. 40).

Niezbędne do wygenerowania wartości dodanej dla każdego klienta firmy są jej zasoby. Dlatego w celu jak najefektywniejszego dotarcia do klienta należy określić kluczowe zasoby przedsiębiorstwa. Istnieje wiele klasyfikacji zasobów, jednak przy tworzeniu modelu biznesowego metodą Canvas warto skorzystać z podziału zasobów zaproponowanego przez A. Osterwaldera. Wyróżnia on kategorie: zasoby fizyczne, intelektualne, ludzkie oraz finansowe (Osterwalder, Pigneur, 2012, s. 38).

Na dzisiejszym rynku przedsiębiorstwa nie działają w odosobnieniu, odizolowane od zewnętrznych podmiotów. Coraz częściej słyszy się o wykorzystywaniu outsourcingu, zawieraniu sojuszy strategicznych i aliansów. Współpraca ta ma na celu wzmocnienie obecnej pozycji przedsiębiorstwa na rynku, prowadzi do obniżenia kosztów, a także zapewnia bezpieczeństwo finansowe (Osterwalder, Pigneur, 2012, s. 43).

\subsection{Elementy modelu Canvas dotyczące pozycji finansowych}

Działania każdego przedsiębiorstwa ukierunkowane są na osiąganie jak najwyższych zysków przy jednoczesnym minimalizowaniu kosztów. Dlatego w modelu biznesowym nie mogło zabraknąć elementów dotyczących kosztów oraz generowania przychodów. 
Struktura kosztów opisuje najważniejsze koszty, jakie firma ponosi w ramach swojej działalności w oparciu o określony model organizacyjny. Wszystkie aktywności, których podejmuje się przedsiębiorstwo, wiążą się z procesem generowania kosztów - mogą to być m.in. czynności związane z tworzeniem i dostarczaniem wartości dla klienta, bądź utrzymywaniem relacji z klientem. Jak zostało już wcześniej wspomniane, wszystkie elementy modelu biznesowego wzajemnie na siebie wpływają i są od siebie zależne, dlatego struktura kosztów w dużej mierze będzie zależeć od infrastruktury, określonej w modelu jako kluczowe czynności, zasoby, sieć partnerów (Osterwalder, Pigneur, 2012, s. 44-45).

Ostatnim omawianym elementem modelu Canvas, ale najważniejszym z punktu widzenia przedsiębiorstwa, jest struktura przychodów. Element ten opisuje sposób i ilość generowanych przez firmę środków wpływających z obsługi poszczególnych segmentów klientów. Mechanizmy generowania przychodów mogą być różne; najczęściej spotykane są te związane ze sprzedażą aktywów, oferowaniem abonamentu, pobieraniem opłaty za korzystanie, czy też pobieraniu prowizji z tytułu pośrednictwa (Osterwalder, Pigneur, 2012, s. 34-35).

Wszystkie opisane elementy stanowią całość szablonu modelu Canvas. Choć coraz częściej pojawia się krytyka tego projektu, jego zwolennicy nadal twierdzą, że jest to podejście elastyczne, które można zastosować $\mathrm{w}$ firmach $\mathrm{z}$ różnych branż. Niewątpliwie największą zaletą tego modelu jest umiejscowienie propozycji wartości w centrum odzwierciedla to dzisiejszy trend na rynku związany z ukierunkowaniem na klienta.

\section{Podsumowanie}

Agresywne działanie konkurencji i ciągłe poszukiwanie nowych sposobów generowania przychodów zmusza firmy do tworzenia coraz to bardziej innowacyjnych modeli biznesowych. Choć jest to w Polsce termin stosunkowo młody, zauważalny jest wzrost zainteresowania tą tematyką. Przykłady znanych marek (np. Apple) dowodzą, że dostrzeganie kreatywności i innowacji w podejściu do modeli organizacyjnych ułatwia firmie wyróżnienie się na rynku oraz sprawia, iż gotowa jest stawić czoło stojącym przed nią wyzwaniom; kreatywność i innowacje stają się zatem skuteczną determinantą procesu zarządzania firmą. Ważne jest, aby dokładnie zrozumieć istotę modelu biznesowego oraz w szczegółowy sposób określić jego elementy - tak by model stał się obrazem przedsiębiorstwa.

Jednym z najczęściej stosowanych szablonów służących do tworzenia innowacyjnych modeli biznesowych jest szablon Canvas opracowany przez A. Osterwaldera. Model ten składa się z 9 elementów i główną rolę odgrywa w nim klient - cena ma coraz mniejsze znaczenie. Jak trafnie spostrzegł A. Osterwalder, „jeżeli uznamy, że klienci stanowią serce modelu biznesowego, wówczas strumień przychodów należy uznać za jego układ krwionośny". 


\section{BIBLIOGRAFIA}

[1] Afuah A., Tucci C., 2003, Biznes internetowy. Strategie i modele, Oficyna Ekonomiczna, Kraków.

[2] Christensen C., Johnson M., Kagermann H., 2008, Reinventing Your Business Model, „Harvard Business Review", Nr. 86.

[3] Eyring M.J., Johnson M.W., NAir H., 2012, Nowe modele biznesowe. Sposób na podbój rynków wschodzących, „Harvard Business Review Polska”, Nr 111.

[4] Jankowski W., Jonhnson M., 2013, Rozwój przez innowacje w modelu biznesowym, „Harvard Business Review Polska", Nr 127.

[5] Magretta J., 2003, Tajniki modelu biznesowego, „Harvard Business Review Polska”, Nr 1.

[6] Nogalski B., 2011, Modele biznesu jako narzędzia reorientacji strategicznej przedsiębiorstw, [w:] W. Kieżun (red.), Krytycznie i twórczo o zarzadzaniu: wybrane zagadnienia, Wolters Kluwers Business, Warszawa.

[7] Овєó К., 2002, Tworzywo skutecznych strategii, Polskie Wydawnictwo Ekonomiczne, Warszawa.

[8] Osterwalder A., Pigneur Y., 2012, Tworzenie modeli biznesowych. Podręcznik wizjonera, Wydawnictwo Helion, Gliwice.

[9] Timmers P., 1998, Business models for electronic markets, „Electronic Markets”, 8(2).

[10] WierzbiŃski M., 2015, Model biznesowy a strategia i zarządzanie strategiczne, [w:] M. Kowalewski, E. Nowak (red.), Zarzadzanie kosztami i dokonaniami, „Prace naukowe Uniwersytetu Ekonomicznego we Wrocławiu", Nr 398.

\section{NETOGRAFIA}

[1] GOOGLE, 2016, https://www.google.pl/trends/explore?date=all\&geo=PL\&q=model\%20canvas (4.12.2016).

[2] StęPNiewicz S., 2012, Business Model Canvas - myślenie modelem biznesowym, http://www. pi.gov.pl/PARP/chapter_86196.asp?soid=0E6E586112814614843715A84D46939C (12.12.2016).

[3] Tomaszewski T., 2014, Business Model Canvas - szablon modelu biznesowego, https://productvision.pl/2014/business-model-canvas-szablon-modelu-biznesowego/ (7.12.2016).

[4] KoŁodziej R., 2012, Business model Canvas czy Lean Canvas?, http://cocreation.bblog.pl/wpis, business;model;canvas;czy;lean;canvas,67100.html (21.12.2016).

[5] PWN, 2016a, Słownik języka polskiego, Hasło 'model', https://sjp.pwn.pl/sjp/model;2484153.html (7.12.2016).

[6] PWN, 2016b, Słownik języka polskiego, Hasło 'biznes', https://sjp.pwn.pl/sjp/biznes;2552335.html (7.12.2016).

[7] WEB.GOV.PL, 2016, Business Model Canvas, http://www.web.gov.pl/wiedza/pomysl-na-ebiznes/621_2075.html (13.12.2016). 
